\title{
El P. Feijoo, polígrafo, según Menéndez Pelayo
}

\author{
por Francisco SERRANO CASTILLA
}

Catedrático del Instituto de Enseñanza Media Eusebio da Guarda', do La Coruña

El P. Feijoo es una de las personalidades más relevantes de nuestras Letras y de nuestra cultura, por el valor de su obra y por la especial significación de la misma. No vamos a repetir, una vez más, sus títulos, tan justamente conquistados, de debelador de la superstición y del error; de patriota, en la más noble y exacta acepción de la palabra, que quería que su patria estuviese en todo a la mayor altura y deseaba por ello incorporarla a todo progreso cultural y científico; de creador de la prosa científica española; de verdadero ensayista en el sentido moderno del término, que inicia un género que va a ser, después, de glorioso arraigo y fecundos resultados en la Literatura española. El P. Feijoo es indiscutiblemente un científico y un erudito, hablando en términos generales, y aunque no fuesen la erudición y la ciencia su única y firme especialización.

El monje de Samos y catedrático de Oviedo es un teorizador de la literatura y un escritor de intuición y perspicacia críticas, y debiera ser más considerado y tenido en cuenta en estos aspectos.

Pero, ante todo y sobre todo, el P. Feijoo es un polígrafo, en el más 
preclaro y augusto sentido de la palabra, el que tiene en aquellas conferencias que pronunció el inmortal D. Marcelino Menéndez Pelayo en la Cátedra de la Escuela de Estudios Superiores del Ateneo de Madrid, durante cinco cursos, de 1896 a 1901. En dichas conferencias, de las que tenemos las reseñas de la época, el polígrafo por antonomasia nos dice lo que sigue, a través de la publicada por Manuel Multedo en El Globo, de Madrid, que, si no responde totalmente a la forma, sí es fiel expresión del pensamiento del genio montañés, quien conoció y aprobó estas reseñas, recogidas después en Menéndez-Pelayismo: ${ }^{1}$

«El nombre de polígrafo puede tomarse en dos distintas acepciones, conformes ambas con el valor etimológico de la palabra.

Llámanse polígrafos en el más vago y general sentido aquellos autores que han cultivado diversas ramas de la literatura, ya científica, ya amena, y es claro que los escritores de tal género abundan en todas las literaturas. Pero aquí no llamamos polígrafo al que haya sido a un tiempo, como lo fue Lope de Vega, poeta dramático, épico, lírico, novelista, ni al que haya sobresalido en varias ciencias a la vez, siendo, por ejemplo, filósofo, naturalista y médico, como lo fueron Andrés Laguna y Vallés, sino que buscamos otro concepto más trascendental que informe nuestra enseñanza y le preste unidad.

Para declarar este concepto, conviene tener presente que la historia de la cultura humana en general, lo mismo que la peculiar historia de la civilización de cada pueblo, puede ser expuesta por dos diversos métodos que responden a las dos capitales direcciones del pensamiento en toda investigación racional sobre el sujeto humano y sus obras en el espacio y en el tiempo.

$\mathrm{Y}$ aunque cada cual de estas direcciones, si aisladamente se la cultiva, pueda conducir a perniciosos exclusivismos, también es cierto que entre las dos, debidarnente ponderadas y armonizadas, pueden agotar íntegramente el rico contenido de la historia; y no hay grave riesgo en preferir para la exposición una de ellas, siempre que no se pierda de vista la restante. Es decir, que, o bien se considera la historia por el lado social, colectivo, impersonal, estudiándose principalmente los caracteres étnicos, las fuerzas intelectuales de la raza, el desarrollo de los organismos sociales, las aptitudes científicas y estéticas colectivas, los elementos que han favorecido su desarrollo y los obstáculos que se han opuesto a él, y éste es el más seguro camino, quizás el único, para explicar los grandes esfuerzos de la colectividad, los monumentos que pudiéramos llamar anónimos, tales como la elaboración del derecho y de la poesía épica; o bien se atiende al elemento individual histórico que se revela triunfalmente en los grandes capitanes, en los grandes

1. Menéndez-Pelayismo, Publicación de la Sociedad de Menéndez Pelayo. Marcelino Menéndez Pelayo. Los Grandes Poligrafos españoles. Estudios y Bibliografia Menéndez-Pelayista, Santander, 19 de mayo de 1944. XXXII Aniversario de su muerte. 
FEIJOO, POLIGRAFO

legisladores, en los artistas soberanos, en los inmortales escritores y hombres de ciencia.

Ambos escollos pueden y deben evitarse en la recta disciplina del espíritu, $y$, por lo que a nosotros toca, sin pecar de intransigente individualismo, y reconociendo, como de buen grado reconocemos, que la obra de la cultura de un pueblo es labor esencialmente colectiva, no podemos menos de afirmar con igual resolución que la conciencia de los pueblos y de las razas, así como la conciencia universal del género humano, se revela y manifiesta de un modo más concreto y luminoso en un corto número de hombres privilegiados, a quienes ya Fray José de Siguienza llamó «hombres providenciales», y en nuestros tiempos ha llamado Carlyle los «héroes» y Emerson los «hombres representativos».2

Hemos hecho una cita amplia, porque es suficientemente expresiva.

Ya en aquellas conferencias D. Marcelino nos habla del P. Feijoo en el sentido que indicamos. Veamos sus palabras, o, mejor dicho, su pensamiento, a través de la reseña de Multedo:

«El Padre Feijoo, Hervás y Panduro y Jovellanos son las destacadas figuras del siglo XVIII.

El Padre Feijoo, a quien tanto debió la cultura española; Hervás y Panduro, más enciclopédico y fundador de la filología comparada, y don Gaspar Melchor de Jovellanos, que trató de tan diversas materias en sus numerosos ensayos, adornando el espíritu español con el extranjero.

Estos tres serán los últimos insignes varones que atesoraron conocimientos que habremos de estudiar en esta cátedra sin alardes oratorios y trabajando sólo sobre los textos inspirados por el fruto de la propia investigación y auxiliados por el de la ajena experiencia ya depurada.s ${ }^{3}$

Es claro que el Maestro de nuestras Letras - que, ciertamente, no escribió mucho sobre Feijoo y que no siempre lo poco que dijo de él fue favorable al eximio benedictino- consideraba, no obstante, en su genial visión y valoración de nuestra cultura, que el catedrático ovetense era un verdadero poligrafo, es decir, un hombre representativo de la cultura española de su tiempo. ${ }^{4}$

Otro de los autores de reseñas de estas conferencias sobre «Los grandes polígrafos españoles», Pascual de Liñán y Eguizábal, que escribió la de la primera y segunda lección en La Ciudad de Dios, y que también

2. Ob. cit, ps. 3 y 4 .

3. Ob. cit., ps. 11-12.

4. De esto nos hemos ocupado con más amplitud en nuestra conferencia en la Real Abacía de Samos, dentro de la Semara Feijoniana, sobre Feijoo y Menéndez Pelayo. 
las sometió a la aprobación de Menéndez Pelayo, recoge así lo referente al P. Feijoo:

"En el mismo siglo xvini destácanse tres nombres cuya importancia en vano fuera discutir. Feijoo, viviente enciclopedia de su tiempo; verdadero archivo del saber popular, y su martillo no pocas veces, luchó denodadamente en pro de nuestra cultura tradicional, que tan bien demostraba conocer, rompiendo lanzas contra todo viento de barbarie, e iniciando, quizás el primero, y antes de ser escritor por «disposición real», la publicación periódica, casi siempre madura, que en nuestros días, con humos de profundidad, todo lo arrolla y lo comprende todio. En él, además, podemos estudiar con provecho el último baluarte donde se defendió la, cuando Dios quería, potente Filosofía española.»5

El texto de Liñán es, ciertamente, ejemplar para confirmación de nuestra tesis.

Es lástima grande que no haya más reseñas de las repetidas conferencias que las que ofrece D. Enrique Sánchez Reyes en Menéndez-Pelayismo, y más todavía que D. Marcelino suspendiese sus explicaciones en el curso de 1900 a 1901, como muy bien dice su citado biógrafo Sánchez Reyes. $^{6}$

Pero en cualquier caso queda sobradamente reflejado, y esto es lo que nos interesa, el concepto que el más exacto definidor de la cultura española tiene de Feijoo como de polígrafo del siglo xvirr. No llegó a tratar a fondo de Feijoo.

Creemos que, aunque el P. Feijoo goza de indudable prestigio, no se ha hecho a su figura la debida y total justicia a que es acreedor, y consideramos que debe aprovecharse la ocasión tan propicia que nos presenta la conmemoración del segundo centenario de su muerte para insistir en ello y que quede totalmente esclarecida en todos los aspectos la personalidad de este gran español de la decimoctava centuria, que, como todos los polígrafos, presenta caras y aspectos muy diversos, variados e interesantes.

5. Ob. cit., p. 11 .

6. Ob. cit., Presentación y Programa, XVII. 